\title{
BURYING THE UNDEAD: COMING TO TERMS WITH THE SOVIET PAST IN NOVELS BY OL'GA SLAVNIKOVA AND SERGEI LEBEDEV
}

ALENA HEINRITZ

KARL-FRANZENS-UNIVERSITÄT GRAZ

\begin{abstract}
I ask how novels by Ol'ga Slavnikova and Sergei Lebedev reflect the possibility of reconciliation between the post-Soviet present and the Soviet past in Russia and the contemporary politics of history. Both novels will be read in the context of "magical historicism" (Etkind), a genre that uncovers the legacy of traumatic past events in the present time using elements of the grotesque. After discussing the concepts of spectrality (Marx, Derrida) and hauntings by the "unburied" (Etkind), I argue that specters and other similar figures reflect mediality. In the two case studies, I present haunting as a reflection of the problems that arise in the attempt to delineate communism and the Soviet past in discourse. Discursive delineation, I argue, is a precondition for coming to terms with the Soviet past.
\end{abstract}

Keywords: Lebedev; Slavnikova; Russian literature; communism; reconciliation; spectrality; trauma

DOI: $10.14712 / 23363231.2018 .4$

\section{The Specter of Communism}

The spectral, the gloomy, the grotesque, and the undead often appear - for different reasons - as figurations within the discourse of communism. The

\footnotetext{
Alena Heinritz is a research assistant at the Center for Cultural Studies at the University of Graz. Address correspondence to Alena Heinritz, Karl-Franzens-Universität Graz, Zentrum für Kulturwissenschaften, Attemsgasse 25/II, A - 8010 Graz.

E-mail: alena.heinritz@uni-graz.at.
} 
"Manifesto of the Communist Party" (1848) comes immediately to mind. At the beginning of the "Manifesto," Marx and Engels write:

A spectre stalks the land of Europe - the spectre of communism [...]. It is high time for communists to lay before the world their perspectives, their goals, their principles, and to counterpose to the horror stories of communism a manifesto of the party itself. ${ }^{1}$

The authors use the "specter of communism" as a metaphor for the yet to be defined or declared aims of communism. The manifesto is meant to make the vague become manifest. Derrida, however, describes the "Manifesto" as a

presentation of the living reality: we must see to it that in the future this specter [...] becomes a reality, and a living reality. [...] The universal Communist Party, the Communist International will be, said the Manifesto in 1848, the final incarnation, the real presence of the specter, thus the end of the spectral. ${ }^{2}$

Derrida therefore understands Marx and Engels's "specter of communism" as a utopia awaiting its realization.

From a critical perspective, people living in such a yet-to-be-incarnated utopian version of society are described as spectral figures. Boris Groys claims that the figuration of the specter originated with the outside enemies of communism who stated that "[t]he reality of communism has no depths; it is a case of a merely mediating surface." The people living in societies on their way to communism are seen by their opponents as "empty shell[s]: the interior, the human flesh as such, is absent." ${ }^{3}$ Viktor Pelevin, in his essay "Zombifikatsiia" (1990, "Zombification"), compares the Soviet man with a Haitian zombie that has been forced into unconditional servitude by his master with the help of magical rituals, leaving him no will of his own. According to Pelevin, one need only think of the inhuman Soviet discourse, with all its contradictions and acronyms, to see the extent to which its users are "zombified."

1 Karl Marx and Friedrich Engels, "Manifesto of the Communist Party," in Later Political Writings, by Karl Marx, ed. and trans. Terrell Carver (Cambridge: Cambridge University Press, 1996), 1.

2 Jacques Derrida, Specters of Marx. The State of the Debt, the Work of Mourning, and the New International, trans. Peggy Kamuf (New York, London: Routledge, 1994), 101-103; see also: "time rejoins and adjoins itself here, now, a now that happens to itself in the act and the body of this manifestation." Ibid., 103.

3 Boris Groys, The Communist Postscript, trans. Thomas H. Ford (London, New York: Verso, 2009), 81-82.

4 Viktor Pelevin, “Zombifikatsiia. Opyt sravnitel'noi antropologii," in Vse povesti i esse, by Viktor Pelevin (Moskva: Eksmo, 2005), 380. 
Derrida conceptualizes spectrality from a wider perspective. In his essay "Spectres de Marx" (1993) he describes spectrality as a consequence of the lack of justice in contemporary society and writes about the principle of responsibility "beyond all living present":

It is necessary to speak of the ghost, indeed to the ghost and with it, from the moment that no ethics, no politics, whether revolutionary or not, seems possible and thinkable and just that does not recognize in this principle the respect for those others who are no longer or for those others who are not yet there, presently living, whether they are already dead or not yet born. No justice [...] seems possible or thinkable without the principle of some responsibility, beyond all living present, within that which disjoins the living present, before the ghosts of those who are not yet born or who are already dead, be they victims of wars, political or other kinds of violence. ${ }^{5}$

Justice, says Derrida, can be maintained only with regard to the living. Therefore the living have to reckon with the presence of the ghosts that are "living-on [sur-vie]," 6 for the sake of justice.

Derrida expects from the state of "being-with specters" a more just life, with a "politics of memory, of inheritance, and of generations." Here he takes up Walter Benjamin's concept of a "weak messianic power" that, according to Benjamin, has been given to every man and that holds human beings responsible not only for the present and future, but also for the past, in a "secret agreement between past generations and the present one." 8 It is now quite obvious that the concept of time underlying Derrida's "hauntology" cannot be linear. Derrida assumes that it is the "time out of joint" that gives rise to the spectral moment. ${ }^{10}$

${ }^{5}$ Derrida, Specters of Marx, xix. The idea of solidarity between the living, the dead, and those living in the future can be traced back to Edmund Burke, who considered society to be a contract among people in the past, present, and future. See Edmund Burke, Revolutionary Writings. Reflections on the Revolution in France and the First Letter on a Regicide Peace, ed. Iain Hampsher-Monk (Cambridge: Cambridge University Press, 2014), 101; see Alexander Etkind, Warped Mourning. Stories of the Undead in the Land of the Unburied (Stanford: Stanford University Press, 2013), 206-207.

${ }^{6}$ Derrida, Specters of Marx, xx.

7 Ibid., xix.

${ }^{8}$ Walter Benjamin, "On the Concept of History," in Selected Writings. Vol. 4: 1938-1940, by Walter Benjamin, trans. Edmund Jephcott et al., ed. Howard Eiland and Michael W. Jennings (Cambridge, London: The Belknap Press of Harvard University Press, 2003), 390; Derrida, Specters of Marx, 55; see Derrida's location of the "memory of the hope" at the heart of the "place of spectrality" (ibid., 65).

9 Ibid., 10.

10 See Derrida's discussion of Shakespeare's protagonist Hamlet and his declaration that "[ $t$ ]he time is out of joint" (ibid., e.g., 17). 
Communism in this respect is spectral because of its focus on the future, and as a consequence it ceaselessly haunts the present: "a ghost never dies, it remains always to come and to come-back."11

\section{Hauntings by the Undead in Post-Soviet Culture}

In his writings, Alexander Etkind has repeatedly pointed out how the "unburied, unwept Soviet experience"12 haunts post-Soviet culture. Etkind criticizes Derrida because he assumes that the living cannot possibly give justice to the dead. The ghosts haunting post-Soviet society, he says, need nothing more than recognition, which is something the living can definitely give them. ${ }^{13}$ Etkind refers in his discussion to Sigmund Freud's essay "Mourning and Melancholia." ${ }^{14}$ Freud believed that "unsuccessful" mourning and repressed memories are expressed in melancholy. Melancholy, in turn, makes the past return cyclically to the present and leads to the subject's total identification with the object. ${ }^{15} \mathrm{It}$ is on this theory that Etkind bases his hypothesis about the post-Soviet period:

The post-Soviet period is, undoubtedly, a time of melancholy. The work of mourning is incomplete and unsuccessful; the loss has been incorporated into the subject, who cannot (meaning that he does not want to) free himself from it [...]. But what is this loss? For some it is the unburied millions of Soviet victims; for others, by contrast, it is the grandeur of the Soviet empire. ${ }^{16}$

${ }^{11}$ Ibid., 99.

12 Mark Lipovetsky and Alexander Etkind, "The Salamander's Return: The Soviet Catastrophe and the Post-Soviet Novel," trans. Liv Bliss, Russian Studies in Literature 46, No. 4 (Fall 2010): 14, doi: 10.2753/RSL1061-1975460401; see also: "In a land where millions remain unburied, the dead return as the undead." Alexander Etkind, "Magical Historicism," in Russian Literature Since 1991, ed. Evgeny Dobrenko and Mark Lipovetsky (Cambridge: Cambridge University Press, 2015), 118. See Gudkov and Zorkaja about the reasons for the inability of present Russian society to come to terms with the Soviet past. Lev Gudkov and Natalija Zorkaja, "Instrumentalisieren, Klittern, Verdrängen. Russlands unerwünschtes Revolutionsjubiläum," trans. Vera Ammer, Osteuropa 67, No. 6-8 (2017): 38.

13 Etkind, Warped Mourning, 219.

${ }^{14}$ Sigmund Freud, "Mourning and Melancholia," in The Standard Edition of the Complete Psychological Works of Sigmund Freud, Vol. XIV: (1914-1916), trans. and ed. James Strachey (London: The Hogarth Press and the Institute of Psycho-Analysis, 1995), 243-258.

${ }^{15}$ Lipovetsky and Etkind, "The Salamander's Return," 8-9; see also Freud, "Mourning and Melancholia," 249.

${ }^{16}$ Lipovetsky and Etkind, “The Salamander's Return," 9. See also: "In Eastern Europe, we discern neither reconciliation nor oblivion [...]. There are psychic and cultural processes in which an obsession with the past prevents the subject from discerning the present." Alexander Etkind, Foreword to War and Memory in Russia, Ukraine and Belarus, ed. Julie Fedor et al. (Cham: Palgrave 
Referring to Freud's essay "The Uncanny," 17 Etkind writes that what is repressed returns in grotesque form in post-catastrophy memories. ${ }^{18}$ According to Etkind, the work of mourning, which often remains incomplete, is in the first place done in literature. ${ }^{19}$ In this context, it is important to keep in mind that the traumatic evades being framed by language. ${ }^{20}$ The evasion of discursive fixation complicates dealing with trauma - both individual and collective - because the trauma cannot be adequately processed, thematized nor categorized. ${ }^{21}$ The unarticulated moment, then, gives rise to spectrality and the repetition of history. ${ }^{22}$ In this sense, Kathleen Brogan underlines the possibility of coming to terms with traumatic past by means of translation into language:

The saving movement from reenactment to enabling memory is, therefore, a movement into language. Through acts of narrative revision - which are very often presented as acts of translation, linguistic or cultural - the cycle of doom is broken and the past digested. Translation functions like an exorcism because it reframes cultural inheritance, rendering the past in the terms of the present [...]. The ghost that makes present the past while suggesting its indefiniteness (and thereby possible malleability), thus provides the vehicle for both a dangerous possession by and an imaginative liberation from the past. ${ }^{23}$

Macmillan, 2017), ix; see also Mark Kramer, "Public Memory and the Difficulty of Overcoming the Communist Legacy: Poland and Russia in Comparative Perspective," in Totalitarian Societies and Democratic Transition. Essays in Memory of Victor Zaslavsky, ed. Tommaso Piffer and Vladislav Zubok (Budapest, New York: Central European University Press, 2017), 421.

17 Sigmund Freud, "The Uncanny," in The Standard Edition of the Complete Psychological Works of Sigmund Freud. Vol. XVII: (1917-1919), trans. and ed. James Strachey (London: The Hogarth Press and the Institute of Psycho-Analysis, 1995), 219-252.

18 Etkind, Warped Mourning, 220. See: “[...] for this uncanny is in reality nothing new or alien, but something which is familiar and old-established in the mind and which has become alienated from it only through the process of repression. This reference to the factor of repression enables us, furthermore, to understand Schelling's definition [...] of the uncanny as something which ought to have remained hidden but has come to light." (Freud, "The Uncanny," 241.)

${ }^{19}$ Lipovetsky and Etkind, "The Salamander's Return," 9.

${ }^{20}$ See, e.g., Jenny Edkins, Trauma and the Memory of Politics (Cambridge: Cambridge University Press, 2013), 38; Bessel van der Kolk, "Trauma and Memory," in Psychiatry and Clinical Neurosciences 52, No. 1 (1993): 52-64, doi: 10.1046/j.1440-1819.1998.0520s5S97.x.

${ }^{21}$ See Edkins, Trauma and the Memory of Politics, 39-40.

22 See George Santayana's statement, which has become a common dictum when referring to the post-Soviet situation: “Those who cannot remember the past are condemned to repeat it." George Santayana, The Life of Reason or the Phases of Human Progress (New York: Charles Scribner's Sons, 1954), 82; see also Anatoly Khazanov, "Whom to Mourn and Whom to Forget? (Re)constructing Collective Memory in Contemporary Russia," in Totalitarian Movements and Political Religions 9, No. 2-3 (June-September 2008): 308, doi: 10.1080/14690760802094917.

${ }^{23}$ Kathleen Brogan, "American Stories of Cultural Haunting: Tales of Heirs and Ethnographers," College English 57, No. 2 (Feb. 1995): 156, doi: 10.2307/378807. 
Following up and expanding Brogan's thought, I argue that discursive delineation in literary narratives can be a step toward a dynamic mnemonic process and coming to terms with the Soviet past.

Of course, we must differentiate between the "specter of Communism" (Marx) and post-Soviet haunting by the past (Etkind). Nevertheless, both ideas are connected by a common basis in the "time out of joint." First of all, the post-Soviet present has to find a way from utopia (future) back to historical time. Groys, for example, describes post-communist life as going backwards, against the flow of time ${ }^{24}$ and Iampolski attributes to it a melancholy of "the timeless time." 25 Furthermore, post-Soviet time is haunted by a vision of the future that is burdened by trauma. Layers of time are laid one on top of the other and the future collides with historical visions of the future. Literature, in particular, is able to create, bend, and semanticize temporal relationships, ${ }^{26}$ and consequently depict time beyond linearity, giving form to the specters that arise out of complicated temporal situations like this.

Etkind proposes the term "magical historicism" to describe literary approaches that allow alternatives for a representation of the past that is considered as deficient:

When politics does not provide alternatives, historiography offers them in abundance. The hauntological idea of justice becomes relevant when the real courts deny hope; in a similar way, allegories bloom when other ways of constructing truth and memory betray the storyteller. Combining catastrophic past, pathetic present, and dangerous future, early twenty-first-century Russia is a greenhouse for ghosts, revenants, and other spectral bodies. ${ }^{27}$

The sociopolitical relevancy of the spectral in literature, of course, can easily be aligned with Brogan's "stories of cultural haunting" that explore "the hidden

\footnotetext{
${ }^{24}$ Boris Groys, "Die postkommunistische Situation," in Zurück aus der Zukunft. Osteuropäische Kulturen im Zeitalter des Postkommunismus, ed. Boris Groys, Anne von der Heiden, and Peter Weibel (Frankfurt am Main: Suhrkamp, 2005), 48.

25 Michail Iampolski, "Die Gegenwart der Vergangenheit," in Zurück aus der Zukunft. Osteuropäische Kulturen im Zeitalter des Postkommunismus, ed. Boris Groys, Anne von der Heiden, and Peter Weibel (Frankfurt am Main: Suhrkamp, 2005), 165.

${ }^{26}$ See, e.g., Stephanie Wodianka, "Zeit - Literatur - Gedächtnis," in Gedächtniskonzepte der Literaturwissenschaft. Theoretische Grundlegung und Anwendungsperspektiven, ed. Astrid Erll, Ansgar Nünning (Berlin, New York: De Gruyter, 2005), 184.

${ }^{27}$ Etkind, Warped Mourning, 235.
} 
passageways not only of the individual psyche, but also of a people's historical consciousness." 28

Drawing upon the following case studies, I claim that the retrospective literary representation of the Soviet past demonstrates different forms of magical historicism. The differences depend on the function of language and narrative used in representation. In the following sections, I present two different forms of magical historicism that I call "immediate" and "mediated magical historicism." I argue that in "immediate magical historicism" the magical and the grotesque operate immediately in the reality of the fictional world and permeate it to such an extent that the protagonists have no possibility of distancing themselves from it. Etkind refers to LaCapra's related concept of "acting out":

Acting out is related to repetition, and even repetition compulsion - the tendency to repeat something compulsively. This is very clear in the case of people who undergo a trauma. They have a tendency to relive the past, to be haunted by ghosts or even to exist in the present as if one were still fully in the past, with no distance from it. ${ }^{29}$

The concept of acting out goes back to Freud again: "He [i.e. the patient] reproduces it [i.e., the forgotten and repressed] not as a memory but as an action; he repeats it, without, of course, knowing that he is repeating it." 30 This repetition, according to Freud, "implies conjuring up a piece of real life" 31 which is of course something very like a haunting. I draw on Ol'ga Slavnikova's novel 2017 for an example of immediate magical historicism, ${ }^{32}$ as in Slavnikova's novel, historical artifacts determine the dealings of people, and history takes possession of them like a virus.

The second form of magical historicism, "mediated magical historicism," will be represented here by Sergei Lebedev's novel Predel zabveniia. ${ }^{33}$ In Lebedev's

${ }^{28}$ Brogan, "American Stories of Cultural Haunting," 152.

29 Dominick LaCapra, Writing History, Writing Trauma (Baltimore, London: The Johns Hopkins University Press, 2001), 142-143; see also Lipovetsky and Etkind, “The Salamander's Return," $14-15$.

${ }^{30}$ Sigmund Freud, "Remembering, Repeating and Working-Through (Further Recommendations on the Technique of Psycho-Analysis II)," in The Standard Edition of the Complete Psychological Works of Sigmund Freud. Vol. XII: (1911-1913), trans. and ed. James Strachey (London: Vintage, 2001), 150 .

${ }^{31}$ Ibid., 152.

32 According to Lipovetsky, Slavnikova's novel is one example of the magical historicism coined by Etkind. See Lipovetsky and Etkind, "The Salamander's Return," 13 and 21.

33 The literal translation of the title would be "the border (or: limit) of oblivion," the English translation is titled "Oblivion." 
novel, the magical takes place on an epistemic level, in the perception of the first-person narrator, in his dreams, imaginings, and his descriptions of them. In the beginning the narrator identifies strongly and corporeally with the haunting. By means of reflective narration, though, the narrator succeeds in putting critical distance between himself and the specters of the past. This can be compared to Freud's concept of "working through," which LaCapra conceptualizes as distancing in order to deal with a traumatic memory: working through does not mean avoidance, harmonization, simply forgetting the past, or submerging oneself in the present. It means coming to terms with the trauma." 34 Reflective narration and discursive delineation by the narrator in Lebedev's novel, I argue, finally enable him to bring the haunting to an end.

\section{Russian Society Possessed by the Soviet Past: Ol'ga Slavnikova's Novel 2017}

Ol'ga Slavnikova's novel 2017 was first published in 2006. It is a vision of a future, with a more and more discernible dystopic nature. The plot focuses on its protagonist Krylov, who is working as a gem cutter. In the novel's dystopian prediction of the future, the year 2017 is of vital importance. Costumed parades are staged to celebrate the centenary of the October Revolution. The enactments turn deadly serious when masses of participants, costumed as White Guards and Red Army soldiers, start to attack and kill each other. Security forces are barely able to bring the situation under control. ${ }^{35}$ Violent looting takes place in museums and theaters to seize historical costumes, weapons, ${ }^{36}$ and their replicas for people are striving to take part in the battles - either

${ }^{34}$ LaCapra, Writing History, Writing Trauma, 144. On "working through" see Freud, Remembering, Repeating and Working-Through, 155-156.

35 See, e.g., Ol'ga Slavnikova, 2017. Roman (Moskva: Vagrius, 2006), 374-376; Olga Slavnikova, 2017. A Novel, trans. Marian Schwartz (New York, London: Overlook/Duckworth, 2010), 264-266.

36 There are also attempts to mobilize other means of war: "В Питере революционные матросы захватили филиал военно-морского музея, а именно крейсер 'Аврора', и попытались жахнуть из бакового орудия по отсыревшему Зимнему, увенчанному зелеными, как лягушки, и такими же мокрыми статуями, - но все на крейсере было заварено и толсто покрашено, поэтому дело кончилось всего лишь большим железным грохотом и приводом хулиганов в ближайший участок." (Slavnikova, 2017. Roman, 373-374.) // "In Petersburg, revolutionary sailors had seized a branch of the naval museum - the cruiser Aurora - and attempted to fire a tank gun at the damp Winter Palace; but everything on the cruiser had been welded shut and thickly painted, therefore the matter ended with just a large iron crash and the hooligans being brought in to the nearest police station." (Slavnikova, 2017. A Novel, 264.) 
on the White or the Red side. Battles are refought at their historical sites and White Guards try to win those battles that were won by the Red forces a century before. Criteria such as having a name identical to that of a historical military leader, or a physical appearance similar to one, determine the roles that people play in this new civil war. ${ }^{37}$ Monuments are reconstructed and even the statue of the founder of the Cheka, Felix Dzerzhinsky, is re-erected after having been pulled down in 1991, an act that marked the end of the Soviet rule. ${ }^{38}$

In the novel, such excesses are explained by the characteristics of present-day Russian society in which "a culture of copies without originals," 39 and a "secondary world" 40 rule, governed by "art projects" 41 and actors instead of politicians. No one lives an authentic life anymore, in which friendships, love, and solidarity matter. ${ }^{42}$ Criminality, media, and propaganda rule a "theatricalized" life. ${ }^{43}$ The protagonist Krylov compares the social gulf in twenty-first century Russia between the unbelievably rich and powerful and the disenfranchised to the social problems of one hundred years earlier. According to Krylov, the only difference is that there is no longer any organization that can lead the people to express the social tensions. Because of that, political contestation has to assume a form from the past - the October revolution:

37 Slavnikova, 2017. Roman, 374 and 376; Slavnikova, 2017. A Novel, 264 and 266.

38 Slavnikova, 2017. Roman, 149; Slavnikova, 2017. A Novel, 123.

39 Slavnikova, 2017. A Novel, 187; “культура копии при отсутствии подлинника”. (Slavnikova, 2017. Roman, 239.)

40 Slavnikova, 2017. A Novel, 233; “вторичный мир”. (Slavnikova, 2017. Roman, 335.)

41 "Все политики представляли собой именно арт-проекты: Президент Российской Федерации походил, как никто другой, именно на Президента Российской Федерации, так что после стали выбирать таких же блондинистых силовиков." (Slavnikova, 2017. Roman, 238.) // "All the politicians presented themselves as art projects: the president of the Russian Federation looked so much more like the president of the Russian Federation than anyone else that afterward people kept electing the same kind of blond security-agency types." (Slavnikova, 2017. A Novel, 187.)

${ }^{42}$ E.g. Slavnikova, 2017. Roman, 239 (Slavnikova, 2017. A Novel, 187).

43 “Что получилось в результате? Театрализация жизни, позиционирование всякого питейного заведения и всякой кофейни в качестве сценической площадки, актерство официанток, обилие блескучих телешоу при отсутствии толковых новостей, бесконечные конкурсы красоты без самой красоты. Мы есть то, на что мы похожи." (Slavnikova, 2017. Roman, 240.) // "What was the result? The theatricalization of life, the positioning of any bar or coffeehouse as a stage, the waiters as actors, the abundance of grandiloquent TV shows in the absence of intelligible news and the endless beauty contests without any actual beauty. We are what we resemble." (Slavnikova, 2017. A Novel, 188.) The term "theatricalization of life" was coined by Nikolai Evreinov whose mass re-enactments in the context of the third anniversary of the October Revolution in 1920 shaped the myth of the October Revolution. See, e.g., Igor' Chubarov, “'Teatralizatsiia zhizni' kak strategiia politizatsii iskusstva. Povtornoe vziatie Zimnego dvortsa pod rukovodstvom N. N. Evreinova (1920 god)," in Sovetskaia vlast' i media, ed. Khans Giunter, Sabina Khensgen (Sankt-Peterburg: Akademicheskii proekt, 2006), 281-295. 
- Причина ровно та же, что у Великой Октябрьской социалистической революции, - проговорил Крылов [...]. - Верхи не могут, низы не хотят. Только у нас, в нашем времени, нет оформленных сил, которые могли бы выразить собой эту ситуацию. Поэтому будут использоваться формы столетней давности, как самые адекватные. Пусть они даже ненастоящие, фальшивые. Но у истории на них рефлекс. Конфликт сам опознает ряженых как участников конфликта. Конфликт все время существует, еще с девяностых. Но пока нет этих тряпок - революционных шинелей, галифе, кожанов, - конфликту не в чем выйти в люди. Он спит. А сейчас, в связи со столетним юбилеем, тряпок появится сколько угодно. Так что веселые нас ожидают праздники. ${ }^{44}$

'The reason is the same as in the Great October Socialist Revolution,' Krylov said [...]. 'The rulers are unable and the ruled ones are unwilling. Only in our day and age we don't have formal forces capable of expressing the situation. Therefore, they're going to use hundred-year-old forms, because they're the best we have. Even if they're unreal, false. But history has a reflex to them. The conflict itself recognizes the maskers as the conflict's participants. The conflict has always existed, since the 1990s. We just haven't had these rags yet - the revolutionary greatcoats, riding breeches, and leather jackets. The conflict didn't have anything to wear to go public. It's been slipping. And now, in connection with the centenary, we've got all the rags you want. So we can look forward to some happy holidays. ${ }^{45}$

The proposition that "[t]he rulers are unable and the ruled ones are unwilling" that Krylov quotes here was originally conceived by Lenin as one of the "symptoms" for the "revolutionary situation," the situation with the potential to unleash a revolution. ${ }^{46}$ But the scenes depicted in 2017 and Krylov's explanation for them can be also read as an echo of Marx's statements about historical repetition in "The Eighteenth Brumaire of Louis Bonaparte" (1852):

Hegel observes somewhere that all the great events and characters of world history occur twice, so to speak. He forgot to add: the first time as high tragedy, the second time as low farce [...]. Men make their own history, but they do not make it just as they please in circumstances they choose for themselves; rather they make it in present circumstances, given and inherited. Tradition from all the dead generations

44 Slavnikova, 2017. Roman, 335.

45 Slavnikova, 2017. A Novel, 233.

${ }^{46}$ V. I. Lenin, "The Collapse of the Second International," in Collected Works. Vol. 21: August 1914 - December 1915, trans. Julius Katzer (Moscow: Progress Publishers, 1974), 213-214. 
weighs like a nightmare on the brain of the living. And just when they appear to be revolutionising themselves and their circumstances, in creating something unprecedented, in just such epochs of revolutionary crisis, that is when they nervously summon up the spirits of the past, borrowing from them their names, marching orders, uniforms, in order to enact new scenes in world history, but in this time-honoured guise and with this borrowed language. ${ }^{47}$

According to Marx, the revolutions of the past found their "spirit" in "the resurrection of the dead" of former revolutions. The social revolution of the nineteenth century, in turn, had to "[strip] off all superstition from the past" and leave the dead behind, so that "content transcends phrase." 48

In Slavnikova's novel, the contestations' content is clearly confined to "phrase," but is no less dangerous. The danger of a re-enacted revolution actually did become a central issue in relation to the 2017 centenary of the October revolution in Russia - a real situation that was anticipated in Slavnikova's novel. Ilya Kalinin outlines the context of the Russian government's hesitation when dealing with events related to the centenary. ${ }^{49}$ In 1996 Boris Yeltsin changed the name of the national holiday commemorating the anniversary of the October revolution from "Anniversary of the Great Socialist October Revolution" (Godovshchina Velikoi Oktiabr'skoi sotsialisticheskoi revoliutsii) to "Day of Concord and Reconciliation" (Den' soglasiia i primireniia). The reason for the change was the anxiety of the government that the memory of the revolution would mobilize people to rise up. ${ }^{50}$ From 2005 onwards, November 7 was discontinued as a bank holiday; instead, November 4 was introduced as a holiday celebrating national unity and stability by commemorating the end of the Time of Troubles (smuta) in 1612

47 Karl Marx, "The Eighteenth Brumaire of Louis Bonaparte," in Later Political Writings, by Karl Marx, ed. and trans. Terrell Carver (Cambridge et al.: Cambridge University Press, 1996), 31-32; see also Iampolski's prediction that the Russian society of the 2000 s would be just such a repetition of history - in this case in the form of a parody - in Iampolski, "Die Gegenwart der Vergangenheit," 159; see section 2 of this article.

${ }^{48}$ Marx, "The Eighteenth Brumaire of Louis Bonaparte," 31-32; see also Derrida, Specters of Marx, $107-108$.

${ }^{49}$ Il'ja Kalinin, "Antirevolutionäre Revolutionserinnerungspolitik. Russlands Regime und der Geist der Revolution," trans. Volker Weichsel, Osteuropa 67, No. 6-8 (2017): 11. See also Jan Plamper, "2017. Erinnerung und Verdrängung der Revolution in Russland - zwischen Märtyrologie, Konspirologie und starkem Staat," in 100 Jahre Roter Oktober. Zur Weltgeschichte der Russischen Revolution, ed. Jan Claas Behrends, Nikolaus Katzer, Thomas Lindenberger (Berlin: Christoph Links, 2017), 279-294; and Gudkov and Zorkaja, "Instrumentalisieren, Klittern, Verdrängen," 19-42.

50 See "Ukaz Prezidenta Rossiiskoi Federatsii ot 7 noiabria 1996 goda No. 1537 'O dne soglasiia i primireniia”, http://www.kremlin.ru/acts/bank/10231; Kalinin, "Antirevolutionäre Revolutionserinnerungspolitik," 9-10. 
and the founding of the Romanov Dynasty. ${ }^{51}$ In December 2016, Putin emphasized that he wanted to prevent the anniversary of the revolution from triggering a split in Russian society. ${ }^{52}$ Commemorating the October Revolution could have endangered stability and helped to unleash latent current conflicts. ${ }^{53}$ That is why the centenary of the October Revolution ultimately passed hesitantly and almost unnoticed in Russia ${ }^{54}$ - unlike in Slavnikova's novel.

In the novel, the re-enacted revolution finally leads to civil war and to a collapse of infrastructure. Due to food shortages resulting from the turmoil in the country, old Soviet canned foods are sold that were kept in underground stocks. Among those provisions are huge amounts of reindeer meat that was tinned after a failed nuclear test in the 1950s, with the intention that it would be eaten after the radioactivity had decayed. Slavnikova's narrator compares the tinned reindeer meat to mammoths frozen in the permafrost. ${ }^{55}$ This passage recalls Solzhenitsyn's discussion in the prologue of his Gulag Archipelago of an article that reports on camp prisoners who ate a prehistoric animal, a triton (a kind of a salamander). ${ }^{56}$ According to Etkind, this scene is of central symbolical importance

51 Ibid., 10

52 "Недопустимо тащить расколы, злобу, обиды и ожесточение прошлого в нашу сегодняшнюю жизнь, в собственных политических и других интересах спекулировать на трагедиях, которые коснулись практически каждой семьи в России, по какую бы сторону баррикад ни оказались тогда наши предки." (Poslanie Prezidenta Federal'nomu Sobraniiu, 1.12.2016, http:// www.kremlin.ru/events/president/news/53379.) // "It is unacceptable to drag the grudges, anger and bitterness of the past into our life today, and in pursuit of one's own political and other interests to speculate on tragedies that concerned practically every family in Russia, no matter what side of the barricades our forebears were on." (Presidential Address to the Federal Assembly, December 1, 2016, http://en.kremlin.ru/events/president/news/53379; see Kalinin, "Antirevolutionäre Revolutionserinnerungspolitik," 13.)

53 See ibid., 14. Plamper believed that because of the popular notion of the cyclicity of history in Russia, the "magic" number of 100 years would encourage a revolutionary movement in Russia in 2017. (Plamper, "2017," 290.) The dichotomy between stability and revolution can in this context be aligned with two prevailing political myths in Russia that are dialectically bound together: first, the myth of Russia as an eternal great power and second, the myth of cyclically recurring periods of unrest (Times of Troubles or smuta) "which are instigated from abroad, supported by defectors from within and finally overcome through the united efforts by the people and its resourceful leader(s)." Bo Petersson, "The Eternal Great Power Meets the Recurring Times of Troubles: Twin Political Myths in Contemporary Russian Politics," in European Cultural Memory Post-89, ed. Conny Mithander, John Sundholm, and Adrian Velicu (Amsterdam, New York: Rodopi, 2013), 306.

54 See Gudkov and Zorkaja, "Instrumentalisieren, Klittern, Verdrängen," 19-20 and 22; see also Matthew Rendle, Aaron B. Retish, Introduction to Silences and Noises: Commemorating 1917, Revolutionary Russia 30, No. 2 (2017): 151.

55 Slavnikova, 2017. Roman, 379; Slavnikova, 2017. A Novel, 268.

56 Aleksandr Solzhenitsyn, Archipelag Gulag 1918-1956 (Moskva: Sovetskii Pisatel', Novyi Mir, 1989), 8. 
to how trauma is dealt with in post-Soviet literature: "Solzhenitsyn's salamander paves the way to the post-Soviet literary trauma." ${ }^{7}$ In Slavnikova's novel the Soviet Union "suddenly emerged from underground storehouses to the light of day," together with these cans. ${ }^{58}$ The protagonist Krylov reacts to them with disgust:

Крылову казалось странным употреблять продукты, которым больше полувека: в этом было что-то биологически неправильное, нарушающее естественные циклы. ${ }^{59}$

Krylov thought it was odd to use food that was more than fifty years old. There was something biologically wrong about it, something that violated the natural cycles. ${ }^{60}$

This passage is a very informative example of the special way time is represented in the post-Soviet grotesque. The envisioned utopian future (in which reindeer meat could be eaten without danger of contamination) and the actual future (in which Krylov is living) collide. The tinned reindeer meat is a materialization of the "time out of joint" in the fictional reality of the novel. ${ }^{61}$ Temporal disorder, in turn, leads to the resurrection of forms from the past. ${ }^{62}$ Slavnikova's novel plays with contradictory levels of temporality, satirically "acting out" 63 a scenario that reflects the possession of a collective by a spectrally present past.

\section{A Way of Coming to Terms with the Soviet Past: Sergei Lebedev's Novel Predel zabveniia}

The novel Predel zabveniia (2010) by Sergei Lebedev is about the first-person narrator's research into the past of his so-called "Second Grandfather." ${ }^{64}$ This

57 Lipovetsky and Etkind, “The Salamander's Return,” 8.

58 Slavnikova, 2017. A Novel, 269-270; “вдруг вышедшего из подземных складов на житейскую поверхность”. (Slavnikova, 2017. Roman, 380.)

59 Slavnikova, 2017. Roman, 380.

60 Slavnikova, 2017. A Novel, 269.

61 See Derrida, Specters of Marx, 17-29; see also the narrator's statement about stopping the course of history: "Вот войска, которым не суждено войти в историю, потому что история прекратилась." (Slavnikova, 2017. Roman, 336.) // "Here were troops not fated to go down in history because history had stopped." (Slavnikova, 2017. A Novel, 234.)

${ }^{62}$ See Derrida on Marx's "The Eighteenth Brumaire": "the more the period is in crisis, the more it is 'out of joint,' then the more one has to convoke the old, 'borrow' from it." (Derrida, Specters of Marx, 109.)

${ }^{63}$ See LaCapra, Writing History, Writing Trauma, 142-143; see also section 2 of this article.

${ }^{64}$ The English translator of the novel, Antonina W. Bouis, translated the Russian "Vtoroi ded" ("Second Grandfather") as "Grandfather II." 
research leads him not only out into the Siberian landscape but also into his own memory. To the narrator, his Second Grandfather is not only a close family acquaintance: when he was a child his Second Grandfather twice saved his life, in the end with a blood transfusion that caused the old man's death. This blood connects the narrator with the Second Grandfather even after his death, and takes possession of the boy in a most uncanny way. ${ }^{65}$

The narrator decides to investigate the past after a dream. In his dream, he sees the tracks of prisoners - the victims of state violence - in the snow, which are threatened with erasure by the flow of a river. The dream inspires the narrator's mission to follow the tracks as long as they are still visible. He becomes a "clairvoyant of memory," 66 who alone can ensure that the victims of the past are being remembered. Thus the narrator's exceptional responsibility "for the specters" and for "living against oblivion" 67 is clearly outlined. Like Hamlet in Derrida's essay, he is committed to putting the "time out of joint" back into order. ${ }^{68}$

As a representative of the third generation, the narrator is only an observer in the constellation of victims and perpetrators. Nevertheless, he feels his involvement, because the past physically lives on in his own body. And only because he himself is a part of the past he investigates the narrator gains access to it. His very personal associations and memories allow him to find traces of the

65 “Я снова ощутил, как во мне обращается кровь Второго деда, как растет короткий звериный волос, растут слишком твердые ногти; мне хотелось соскоблить мясо с костей, вылить кровь, вычистить костный мозг.” Sergei Lebedev, Predel zabveniia, 2nd ed. (Moskva: Ėksmo, 2012), 163. // "Once again I sensed Grandfather II's blood circulating in me, I could feel the short animal hairs growing, the too-hard nails growing; I wanted to gnaw meat from bones, ooze blood, suck out the marrow." Sergei Lebedev, Oblivion, trans. Antonina W. Bouis (New York: New Vessel Press, 2016), 122. In this context it is interesting to recall Freud's concept of melancholia arising from the inability of a subject to differentiate himself from the absent object. See Freud, "Mourning and Melancholia," 249; see also section 2 of this article.

${ }^{66}$ Lebedev, Oblivion, 143; “Ясновидец памяти”. (Lebedev, Predel zabveniia, 195.) See the Aristotelian relation between "seer" and "ghost-seer." See Sladja Blažan, "Vernünftiges Geistersehen. Die Politik des Gespenstischen," in 'Lernen, mit den Gespenstern zu leben'. Das Gespenstische als Figur, Metapher und Wahrnehmungsdispositiv in Theorie und Ästhetik, ed. Lorenz Aggermann et al. (Berlin: Neofelis, 2015), 105-106.

${ }^{67}$ Christian Sternad, "Die Zeit ist aus den Fugen. Auf der Jagd nach sterblichen Gespenstern mit Emmanuel Lévinas und Jacques Derrida," in 'Lernen, mit den Gespenstern zu leben'. Das Gespenstische als Figur, Metapher und Wahrnehmungsdispositiv in Theorie und Ästhetik, ed. Lorenz Aggermann et al. (Berlin: Neofelis, 2015), 71.

${ }^{68}$ See "He [i.e., Hamlet] curses the destiny that would precisely have destined him, Hamlet, to do justice, to put things back in order, to put history, the world, the age, the time upright, on the right path [...]. He curses his mission: to do justice to a de-mission of time." (Derrida, Specters of Marx, 20.) 
past and interpret them in the right way. Institutions such as archives and museums do not help him with his research, because they consistently suppress the problematic issues of the Soviet past. ${ }^{69}$ People, too, refuse to be burdened with memory. Instead, objects, sites, and landscapes appear to him as signs that the narrator has to decode; in them he detects impressions of the past and witnesses to long-forgotten incidents:

Я увидел, что речь не о доказательствах, не о буквальном, музейном сохранении вещи - на те, кажущиеся нам неодушевленными, предметы, которые были орудием или просто свидетелями страданий, мук, ложится грозный отсвет; они получают как бы второе бытие, некое подобие голоса, прорываются сквозь собственное косноязычие - сама душа события, квинтэссенция его провиденциального значения поселяется в вещи и говорит с нами. ${ }^{70}$

I saw that it was not about proof or literal, museum preservation of the object - the objects we consider inanimate that were the weapon or merely witnesses of suffering take on a threatening cast; they receive a second existence, a resemblance to a voice breaking through its own stammer - the soul of the event, the quintessence of its providential meaning settles into objects and speaks to us. ${ }^{71}$

In the course of his research, the narrator learns that his Second Grandfather was the commander in a Siberian forced labor camp and that he was responsible for the death of many people.

The peculiarity of the novel rests in the imbedding of the transcendent, spectral, and horrific in the everyday lifeworld of the narrator. It is the narrator's hypersensitive ability to experience that introduces the supernatural and the grotesque into a completely normal everyday reality. The narrator already had this special sensual receptivity as a child, and his retrospective depiction of his childhood is thus characterized by an atmosphere of intangible horror. The "uncanny" emanates from the figure of the Second Grandfather and contaminates landscapes and objects. Due to the Second Grandfather's presence, even the narrator's seemingly peaceful family life is steeped in a threatening light - all the more so because nobody is able to understand the narrator's visions and state of fear.

\footnotetext{
${ }^{69}$ See, e.g., Lebedev, Predel zabveniia, 228; Lebedev, Oblivion, 165.

${ }^{70}$ Lebedev, Predel zabveniia, 131.

${ }^{71}$ Lebedev, Oblivion, 100.
} 
During the Second Grandfather's lifetime, the narrator perceives the Second Grandfather as a "living dead," 72 sensing the ominous presence of death that clings to him. It is unbearable to the narrator to let the Second Grandfather cut his hair, ${ }^{73}$ and when he disregards the child's fear and forces him to drink cold water from a well. By doing so, in the narrator's perception the Second Grandfather turns the child into a naive, but nevertheless initiated, ally of his past in the Siberian forced labor camp. ${ }^{74}$ After his death the Second Grandfather re-encounters the narrator as undead, not in his own corporeal shape but in the shape of objects.

There is an obvious link here between the haunting by the Second Grandfather and the haunting by communism, not only because the Second Grandfather's past was stamped by his service to the cause as commander of a forced labor camp. The death of the Second Grandfather coincides with the collapse of communism, and the narrator relates the formless time between the collapse of the old era and the ushering in of the new to the Second Grandfather's death. ${ }^{75}$

72 “Я ощущал, что он внутренне мертв, рассоединен с миром живых; не призрак, не дух - обстоятельный, телесный, долго живущий [...] мертвец." (Lebedev, Predel zabveniia, 66.) // "I sensed that he was dead inside, unconnected to the world of the living; not a ghost, not a specter - but a solid, physical, long-lived [...] corpse." (Lebedev, Oblivion, 53.)

73 “[...] оно [i.e. бритье] было равнозначно и равносильно смерти. [...] а во мне росло ощущение, что дело не только в стрижке; что Второй дед решил - а никто этого не понимает! - взять меня в свою власть”. (Lebedev, Predel zabveniia, 53-54.) // “[...] a complete shave was equal and equivalent to death. [...] but I had the growing awareness that this wasn't just about the haircut; Grandfather II had decided - and no one understood! - to take me in his power." (Lebedev, Oblivion, 44-45.)

74 “[...] ледяная вода обожгла губы, как металл зимой, а Второй дед стал рассказывать, что далеко на севере вода и летом бывает столь холодна, что у человека останавливается сердце; это не вода уже, а вещество холода. [...] Второй дед словно выбрал меня в младшие товарищи, в наперсники, заведомо зная, что я почти ничего не пойму в том, что скрытыми намеками, умолчаниями, загадками будет открыто мне [...]. Иногда он давал мне ,отпить из кружки - будто бы причащал меня, дозволяя глоток прошлого, которое я не мог ни достоверно представить, ни встроить в более объемную картину." (Lebedev, Predel zabveniia, 72.) // "[...] the icy water burned my lips the way metal does in winter, and Grandfather II started telling me how in the North water can be so cold even in summer that it can stop a man's heart; it wasn't water anymore but the embodiment of cold. [...] Grandfather II had selected me to be a junior comrade, a confidant, knowing that I would understand very little of what would be revealed to me in hints, circumlocutions, and riddles; [...]. Sometimes he gave me 'a sip from the mug' - as if he was giving me communion, permitting me a sip of the past, which I could neither picture accurately nor fit into a bigger picture." (Lebedev, Oblivion, 57-58.)

75 "Вот в эту паузу, во всеобщее оцепенение и пресеклась жизнь Второго деда; [...] новое время, может, и приняло бы его, гибельными оказались промежуток, рассоединенность." (Lebedev, Predel zabveniia, 113.) // "In [sic] was during this pause, this general stupefaction that Grandfather II's life ended; [...] the new era might have accepted him, but it was the interval, the disconnect, that killed him." (Lebedev, Oblivion, 84.) 
As Derrida says, the spectral particularly gains relevance in interjacent and indefinite time and space. ${ }^{76} \mathrm{At}$ first, the narrator feels relieved, expecting that the turn of the eras will release the close corporeal bond he has with the Second Grandfather. ${ }^{77}$ Nevertheless, he is afraid to visit the Second Grandfather's gravesite, fearing the deceased might not be completely dead and may reunite himself with his other half, which is still living in the narrator's body after the blood transfusion. ${ }^{78}$ Despite the narrator's worries, he finally visits the cemetery. There he experiences the haunting of the Second Grandfather for the first time. The narrator identifies a mushroom next to the gravesite as the Second Grandfather's ear:

\begin{abstract}
Ухо - подземный мир слушал, он был здесь, я только не распознал его в сквозящих солнцем приметах дня. И все вернулось: страх, отвращение, озноб; гриб был похож на плоть трупа - и жив существованием растений; Второй дед не отпустил меня. ${ }^{79}$
\end{abstract}

An ear - the underground world was listening, it was here, I just hadn't noticed it in the sunny omens of the day. It all came back: fear, loathing, chills; the mushroom looked like the flesh of a corpse and it lived a vegetative existence; Grandfather II had not let go of me. ${ }^{80}$

76 "What happens between two, and between all the 'two's' one likes, such as between life and death, can only maintain itself with some ghost, can only talk with or about some ghost [s'entretenir de quelque fantôme]." Derrida, Specters of Marx, xviii; see also Lorenz Aggermann et al. "Enter ghost," in 'Lernen, mit den Gespenstern zu leben'. Das Gespenstische als Figur, Metapher und Wahrnehmungsdispositiv in Theorie und Ästhetik, ed. Lorenz Aggermann et al. (Berlin: Neofelis, 2015), 9.

77 "[...] и я увидел, как вместе с временем ушло и то, что составляло - в посмертии - власть Второго деда надо мной; время, подумалось мне, разрешило эти узы." (Lebedev, Predel zabveniia, 118.) // "[...] and I saw that along with time, the thing that comprised Grandfather II's posthumous power over me had also vanished; time, I realized, had loosened those bonds." (Lebedev, Oblivion, 88.)

78 “Во время его похорон я лежал в больнице, а потом с трудом мог приходить на кладбище: мне казалось, что Второй дед не умер до конца, что он поселился во мне, и когда я стою у могилы - это две разобщенные части души Второго деда встречаются друг с другом, одна - неупокоенная, вторая - та, которую я ношу под сердцем, как беременные плод; встречаются - и испытывают сладострастное удовольствие, потому что им удалось обмануть смерть, зацепиться за жизнь [...]." (Lebedev, Predel zabveniia, 113.) // "I was in the hospital during his funeral, and later it was an effort to go to the cemetery: I thought that Grandfather II had not died completely, that he had passed into me, and that when I stood by his grave that two separated parts of Grandfather II's soul encountered one another, one unsatisfied and the other I carried under my heart like a fetus; they met and experienced voluptuous pleasure because they had managed to deceive death, cling to life [...]." (Lebedev, Oblivion, 84.)

${ }^{79}$ Lebedev, Predel zabveniia, 120.

${ }^{80}$ Lebedev, Oblivion, 89. 
With the transfusion of his blood, the Second Grandfather has entered the narrator and lives on inside him after his death. Blood is a common metaphor in national-patriotic expressions of pride and kinship for the continuity between the heroes of Soviet times and the Russian people today. For example, in the "Immortal Regiment" parade blood relationship plays a vital role for memory. ${ }^{81}$ For his part, Lebedev's narrator perceives the blood inside him as a horrible, grotesque blending that feels like a "graft on old wood." ${ }^{82}$ He himself has become a chimera that incorporates the old and the new eras, and both the guilt of the past and the innocence of the future. In that way, he symbolizes the transition between two social formations..$^{83}$

Finally, the narrator encounters the materialized "unburied" past when he finds the corpses of people who have been deported from their homes. ${ }^{84} \mathrm{He}$ buries them and then realizes that he is starting to lose his mind. Only when he is able to clearly identify the specters that are causing him to go insane ${ }^{85}$ does he succeed in ending the haunting of his present by the past. He overcomes the melancholic state that was caused by his blending with the absent object, which had kept the past alive in the present without allowing him to live his life himself. ${ }^{86}$ The narrator then realizes that the blood of the Second Grandfather has definitively left his body ${ }^{87}$ and the traumatic state of the "time out of joint" is thereby overcome, finally enabling him to remember. It is therefore no wonder that the novel ends by reference to its beginning.

${ }^{81}$ See, e.g., Julie Fedor, "Memory, Kinship, and Mobilization of the Dead: the Russian State and the 'Immortal Regiment' Movement," in War and Memory in Russia, Ukraine and Belarus, ed. Julie Fedor et al. (Cham: Palgrave Macmillan, 2017), 310-312.

82 Lebedev, Oblivion, 84; “как черенок, привитый на старое дерево”. (Lebedev, Predel zabveniia, 113.)

${ }^{83}$ See Fuß, whose ideas about carnival as a medium of transition between two incompatible structural orders can partly be applied here. Peter Fuß, Das Groteske. Ein Medium des kulturellen Wandels (Köln, Weimar, Wien: Böhlau, 2001), 353.

${ }^{84}$ Lebedev, Predel zabveniia, 393-394; Lebedev, Oblivion, 277-278.

85 “[...] и теперь, лежа в шлюпке, плывущей к океану, чувствуя в себе безумие, я изнутри этого безумия увидел, как скитаются души, несущие и тяжесть грехов, и беспамятство рождения [...]." (Lebedev, Predel zabveniia, 414.) // "[...] and now, lying in the dinghy sailing to the ocean, feeling my own madness, I could see through that madness the wandering souls bearing the weight of sins and the unconsciousness of birth [...]." (Lebedev, Oblivion, 290.)

86 See Etkind, Warped Mourning, 235-236.

${ }^{87}$ Lebedev, Predel zabveniia, 414; Lebedev, Oblivion, 290. 


\section{Conclusion}

With reference to Derrida, it was stated that the spectral arises in the interjacent spaces, in the interstices between a subject and the external world, between subject and language, ${ }^{88}$ and between reality and the ideal. ${ }^{89}$ It thus functions as a reflection on mediality. ${ }^{90}$ In the two cases I have discussed, the literary figuration of spectral haunting allows reflection on the problems arising from attempts in the post-Soviet period to delineate communism and the Soviet past by means of discourse. This discursive delineation, I argue, is in turn the precondition for the politics of reconciliation, for burying the "undead past," and for memory. Based on Etkind's concept of "magical historicism" I argue that there are two different literary approaches to the presence of traumatic past: by acting out the past, as is done in Slavnikova's novel ("immediate magical historicism"), or by working through the past, as does the narrator in Lebedev's novel ("mediated magical historicism").

Slavnikova's novel 2017 takes on a satirical perspective on current Russian society, depicting the haunting by the Soviet past in explicitly grotesque scenes. It is thus "acting out"91 the common metaphor of the repetition of past events and structures in the present. In the Russian reality that the novel depicts, "natural cycles" are constantly being interrupted. This is where its grotesque dystopian $^{92}$ and spectral ${ }^{93}$ characteristics can be found. The long-forgotten rises to the surface and people absorb it by grotesque processes of blending, ${ }^{94}$ for example,

${ }^{88}$ Gerald Siegmund, “'Un-Fug': Gespenster und das Wahrnehmungsdispositiv des Theaters,” in Subjekt: Theater - Beiträge zur analytischen Theatralität, ed. Gerald Siegmund and Petra Bolte-Picker (Frankfurt am Main: Peter Lang, 2011), 40. See also Link, who situates the appearance of the spectral at the intersection of body and discourse. Jürgen Link, "Das Gespenst der Ideologie," in Gespenster. Erscheinungen - Medien - Theorien, ed. Moritz Baßler, Bettina Gruber, and Martina Wagner-Egelhaaf (Würzburg: Könighausen und Neumann, 2005), 347.

${ }^{89}$ Derrida, Specters of Marx, 63.

90 See Moritz Baßler, Bettina Gruber, and Martina Wagner-Egelhaaf, Introduction to Gespenster. Erscheinungen - Medien - Theorien, ed. Moritz Baßler, Bettina Gruber, and Martina Wagner-Egelhaaf (Würzburg: Könighausen und Neumann, 2005), 11-12.

91 See LaCapra, Writing History, Writing Trauma, 142-143; see also section 2 of this article.

${ }^{22}$ Fuß describes the grotesque with its "anamorphotic mechanisms of liquidating structures: inversion, distortion and blending." These mechanisms "mirror the morphotic mechanisms of structural stabilization: hierarchisation (linearisation), dichotomisation (polarisation) and categorisation (parcellation), that fix a structure by setting the relations between them in perpetuity." (Fuß, Das Groteske, 235, trans. A. H.)

93 "A spectral moment, a moment that no longer belongs to time, if one understands by this word the linking of modalized presents (past present, actual present: 'now,' future present)." (Derrida, Specters of Marx, xx.)

${ }^{94}$ For the grotesque blending, whose product is the chimera, see Fuß, Das Groteske, 349. 
by ingesting food. This leads to a point where the layers of time can no longer be separated. The Soviet period lives on in post-Soviet society without the possibility of being separated from the new one and thus being rejected. Slavnikova's novel reflects this highly problematic temporal confusion. However, the narrated reflection within the frame of the fictional setting is not able to put the "time out of joint" back into order and thus overcome the haunting by the Soviet past.

In contrast to Slavnikova's explicitly grotesque scenes, the uncanny in Sergei Lebedev's novel Predel zabveniia is rooted in the sensitive mind of the narrator, resulting in horror becoming part of his everyday life. The paradox between normality and the concealment of the traumatic past is so glaringly perceived by the narrator that explicit, fantastic horror proves to be superfluous to its literary expression. The paradoxes - for example between the gravesite of the Second Grandfather and his life after death, between domestic intimacy and latent cruelty in the process of cutting hair, and between the beauty of nature and the horror of history at the site of a former forced labor camp $\mathrm{p}^{95}$ - render the everyday grotesque and most uncanny, ${ }^{96}$ without being the least satirical. Lebedev's story succeeds in defining the specters of the Soviet past and trauma is transformed into memory by "working through" 97 - which is, at least, a first step toward coming to terms with the past.

95 “В отвалах штолен была порода, вобравшая в себя смертные усилия людей, удары киркой, кровь и тепло израненных камнем рук, - и теперь эта порода хладно искрилась под солнцем; красота ее не ослабла, не потускнела и потому казалась опасной, цепенящей, как свечение тонкого весеннего льда, под которым - мертвая, лишенная воздуха зимняя вода, полная тленом рыбьего мора. Чтобы перебить, сбросить впечатление, я обернулся. Солнце наполнило светом озеро у подножия хребта; выпуклый, будто капля на стекле, его абрис ударил в зрачки. Недобрая шутка природы - шутка, ждавшая своего часа несколько миллионов лет: у озера были очертания профиля Ленина, впечатанного в подкорку каждому из нас орденами, значками, марками, статуями, картинами, рисунками в книжках." (Lebedev, Predel zabveniia, 133-134.) // "The slag heap had rock that had absorbed the mortal efforts of men, the blows of picks, blood and warmth of hands wounded by the rock, and now that rock was coolly sparkling in the sun; its beauty did not weaken or dim and therefore seemed dangerous, freezing, like the glow of thin spring ice beneath which is the dead, airless winter water, filled with the decay of fish. To break away from this impression, I turned. The sun had filled the lake at the foot of the mountains with light; convex, like a drop on glass, its contour struck me in the eye. A mean trick of nature, a joke that had waited several million years: the lake looked like Lenin's profile, which was imprinted on us by medals, badges, stamps, statues, paintings, and drawings in books." (Lebedev, Oblivion, 102.)

${ }^{96}$ For the relationship between the paradoxical and the grotesque, see Fuß: "The grotesque is a paradoxical category and paradoxy is a grotesque phenomenon. The definition of the grotesque as decomposition of a symbolic cultural order explains this mutual affinity. [...] The impossibility of a clear attribution of a truth value characterises the paradox. [...] It marks the border of the logically resolvable by transgressing it." (Fuß, Das Groteske, 113-114, trans. A. H.)

${ }^{97}$ See LaCapra, Writing History, Writing Trauma, 144. 